\title{
Producing (in) Europe and Asia, $1750-1850$
}

Lissa Roberts, University of Twente

\begin{abstract}
This essay argues for understanding and investigating the history of production, not primarily as a quantifiable economic phenomenon, but as a history of practice that involves the human senses, culture, governance, and material engagement. The vehicle it uses to make its case focuses on a brief examination of production cycles involving salts in various parts of Eurasia during the century that runs from approximately 1750 to 1850 . The essay's approach suggests a history of production in Eurasia that was both locally variegated and transregionally networked. It further involved the interaction between people and their sociomaterial environments, the latter understood as the evolving outcome of interplay between material elements and processes; culturally rooted tastes and values; and variously organized efforts to stimulate, manage, and pursue cycles of production and use. This essay further reflects on how contemporary commentators and present-day historians have (re)configured the geography of these practices in a way that emphasizes divergence between Europe and Asia. Part of this reflection involves looking at what can happen when the historical investigation of production is based on economic analysis. So too does it involve thinking about the potential pitfalls of framing comparative histories.
\end{abstract}

Why this title? First, I am interested in what production entailed across time and space. Exemplified by production cycles involving salts in various parts of Eurasia between approximately 1750 and 1850, this essay suggests the benefits of considering production as practice that involves human senses, culture, governance, and material engagement. This approach yields a history of production in Eurasia composed of locally variegated and transregionally networked activities, in which people interacted with their sociomaterial environments. These environments, in turn, are understood as the evolving outcome of interplay between material elements and processes; culturally rooted tastes and values; and variously organized efforts to stimulate, manage, and pursue cycles of production and use. Second, I want to reflect on how contemporary commentators and present-day historians have (re)configured the geography of these practices, producing narratives focused on divergence between Europe and Asia. Part of this reflection involves looking at the consequences of basing the historical investigation of production on economic analysis. So too does it consider the challenges entailed in framing comparative histories.

Department of Science, Technology, and Policy Studies (STePS), Faculty of Behavioural, Management and Social Sciences, University of Twente, PO Box 217, 7500 AE Enschede, Netherlands; 1.l.roberts@utwente.nl.

Isis, volume 106, number 4. (C) 2015 by The History of Science Society.

All rights reserved. 0021-1753/2015/10604-0008\$10.00 


\section{SALTS IN HISTORY}

Francesca Bray argues that adopting a "more ontological kind of comparison might allow us to escape from the compulsive teleologies of typical global or world history, obsessed as they still are with great divergences and convergences." "Here I use salts to uncover translocal interconnections and exchanges, and to chart local variations and meaningful regional comparisons during the century that runs approximately between 1750 and 1850. A broad range of salts had long been extracted, produced, purified, and utilized in endeavors ranging from food preparation and preservation, to increasing soil fertility; fixing colors in dyes and textiles; and manufacturing soap, porcelain, glass, and gunpowder. Some of the processes involved remained unchanged during this period, though they were perhaps intensified or streamlined, while new ones joined their ranks. What remained constant was the presence of salts as productive lynchpins with enormous consequences for the contexts in which they were put to work.

Common salt was a matter of international competition in Western Europe, especially important for food preservation in connection with long-distance trading voyages. Beyond the challenges of obtaining reliable supplies, entrepreneurs, refiners, and manufacturers had to contend with governmental efforts to manage salt production and trade, and to establish reliable systems of measurement to ascertain composition and purity. These governance practices interacted with developing procedures whereby wastes left behind by salt refining were used to produce chemical salts that, together with other salts and waste products, circulated through urban and rural landscapes, stimulating both manufacturing and agricultural productivity. Production was both threatened and stimulated by the pollution and environmental devastation it brought in its wake. This further encouraged administrators, academic chemists, manufacturers, amateurs, entrepreneurs, and farmers to form complex systems of knowledge exchange and waste recycling that fed the soil, manufacturing, state coffers, stores of knowledge, and social engagement. ${ }^{2}$

Augmenting this history with contemporary interactions with salts in other parts of Eurasia would reveal transregional connections and exchanges, such as those sustained by trade routes that crisscrossed broad expanses of the Eurasian landmass and waterways. So too would this augmented history lay the groundwork for meaningful comparisons. In Japan, for example, long-standing concern with soil depletion made night soil collection and use a standard part of the landscape by the eighteenth century. Transferring wastes from urban to rural areas meant that waterways, where wastes might otherwise have been dumped, remained clean enough to support a thriving fishing industry; excess supplies from the industry were also recycled to rural areas as fertilizer, along with wood ash and industrial wastes from the manufacture of soybean products, sake, and vegetable oils. As culturally specific demand rose, government officials stepped in to regulate prices, while naturalists and entrepreneurs explored new manners of land husbandry and resource use. ${ }^{3}$ This all meshed with an active salt

\footnotetext{
${ }^{1}$ Francesca Bray, "Only Connect: Comparative, National, and Global History as Frameworks for the History of Science and Technology in Asia," East Asian Science, Technology and Societv, 2012, 6:233-241, 238 (quotation).

${ }^{2}$ Joppe van Driel, "Ashes to Ashes: Oeconomic Cycles and the Stewardship of Waste for Agricultural Improvement," History and Technology, 2014, 30:177-206; Van Driel and Roberts, "Circulating Salts: Chemical Governance, Landscapes of Practice and Anthropogenic Concerns," Eighteenth Century Studies (forthcoming); and Jean-Baptiste Fressoz and Thomas le Roux, "Protecting Industry and Commodifying the Environment: The Great Transformation of French Pollution Regulation, 1700-1840," in Common Ground: Integrating the Social and Environmental in History, ed. Geneviève Massard-Guilbaud and Stephen Mosley (Newcastle: Cambridge Scholars, 2011), pp. 340-366.

${ }^{3}$ Conrad Totman, Japan: An Environmental History (London: I. B. Tauris, 2014); Louis Perez, Daily Life in Early Modern
} 
production sector put to wide-ranging purposes, including the production of iconic foodstuffs, ceramics, paints, and dyes.

Regarding China, the presence of salts in various important sectors is easy to identify, including the production and use of dyes and paints to color and decorate the porcelain, silks, and artwork for which China was internationally famous. The stylistic differentiation evident in Chinese ceramics that were sold throughout Eurasia attests to a potent marriage of knowledge of consumers' culturally specific tastes and the ability to cater to them. Longstanding expertise in dye production enabled Canton manufacturers to learn quickly how to produce Prussian blue and similar dyes by the 1820s, shutting recently introduced British imports out of their market- despite British claims to "scientific" superiority. ${ }^{4}$

Tracing networked cycles of salt mining, refining, use, and consumption underscores both transregional connections and comparative insights. Western historians have understandably focused on the Hong merchants who monopolized Canton-based export trade, since Canton was the exclusive center for trade with Europe until 1842. But it was Chinese salt merchants whose wealth and power led them to be known domestically as the "merchant princes" of China. Their wealth, in turn, rested on the ability to extract and purify salt, which were highly developed activities linked by contemporaries to the extraction and use of natural gas, oil and coal, the calcination of limestone, and environmental degradation. Beyond their own borders, Chinese entrepreneurs manufactured salt in places such as the "old salt province" of southern Cambodia. They also operated as itinerant salt sellers, acquiring sufficient income to become significant financiers in the area. ${ }^{5}$

These brief descriptions provide clues to how a salts-centered history of production in Eurasia might look. Extending this history across Eurasia obviously also requires attention to the Ottoman Empire and South Asia. The sympathetic reader, however, should have a sense of what such an approach might yield. Rather than organizing research and interpretations through the filter of preconfigured divergences or convergences between "Europe" and "Asia" (often weighted toward criteria such as "modernization" and economic growth), this approach helps recapture the qualitative elements involved in production born of bodily and cultural sensibility. It further considers production as involving human engagement with materials,

Japan (Greenwich, Conn.: Greenwood Press, 2001); and David Howell, "Fecal Matters: Prolegomenon to a History of Shit in Japan,” in Japan at Nature's Edge, ed. Ian Miller, Julia Thomas, and Brett Walker (Honolulu: Univ. Hawai i Press, 2013), pp. 137-151. On further use of wastes see Conrad Totman, Early Modern Japan (Berkeley: Univ. California Press, 1993); and Federico Marcon, "Satô Nobuhiro and the Political Economy of Natural History in Nineteenth-Century Japan," Japanese Studies, 2014, 34:265-287.

${ }^{4}$ Robert Finlay, The Pilgrim Art: Cultures of Porcelain in World History (Berkeley: Univ. California Press, 2010); and Giorgio Riello and Prasannan Parthasarathi, eds., The Spinning World: A Global History of Cotton Textiles (Oxford: Oxford Univ. Press, 2009), pp. 198-202. On dyes see Kate Bailey, "A Note on Prussian Blue in Nineteenth-Century Canton," Studies in Conservation, 2012, 57:116-121.

${ }^{5}$ On the Hong merchants see Paul van Dyke, Merchants of Canton and Macao (Hong Kong: Hong Kong Univ. Press, 2011); and Van Dyke, The Canton Trade: Life and Enterprise on the China Coast, 1700-1845 (Hong Kong: Hong Kong Univ. Press, 2007). On the Chinese salt merchants see Ping-ti Ho, "The Salt Merchants of Yang-Chou: A Study of Commercial Capitalism in 18th Century China," Harvard Journal of Asiatic Studies, 1954, 17:130-168; and Madeleine Zelin, "The Rise and Fall of the Fu-Rong Salt-Yard Elite: Merchant Dominance in Late Qing China," in Chinese Local Elites and Patterns of Dominance, ed. Joseph Esherick and Mary Backus Rankin (Berkeley: Univ. California Press, 1990), pp. 82-109. On resource extraction and environmental degradation in China see Shu Shuijing, The Classic of the Waterways of Sichuan (1794), excerpted and translated in Mark Elvin, The Retreat of the Elephants: An Environmental History of China (New Haven, Conn.: Yale Univ. Press, 2004), pp. 67-69. On entrepreneurs manufacturing salt outside of China see Nola Cooke, "Tonle Sap Processed Fish: From Khmer Subsistence Staple to Colonial Export Commodity," in Chinese Circulations: Capital, Commodities, and Networks in Southeast Asia, ed. Eric Tagliacozzo and Wenchin Chang (Durham, N.C.: Duke Univ. Press, 2011), pp. 363-371. 
which is stimulated and constrained by acts of governance and environmental conditions, and co-constructive of environmental change. By investigating production as an embodied phenomenon that is interactively embedded in its sociomaterial environment, this approach promises to help us grasp its rich and locally variegated history, and to appreciate current sociocultural considerations and environmental consequences as integrated elements of production, rather than as externalized phenomena.

\section{PRODUCTION AS A CULTURALLY AND SENSIBLY EMBODIED PROCESS}

The word "culture" is difficult to define. Some historians have used it to explain what they consider inherent differences between populations. Samuel P. Huntington, who coined the "Great Divergence" to describe what he saw as a growing gap between Western Europe and China since 1750, argued that essential cultural differences among the world's "civilizations" are responsible for varying states of "development" and war-breeding tensions around the globe. David Landes was equally blunt: "If we learn anything from the history of economic development it is that culture makes all the difference." More nuanced, Margaret Jacob roots her comparative history of industrialization in a particularly British "scientific culture."

Rather than considering "culture" as the identifying characteristic of a historically constructed unit such as "the nation" or a "civilization," I define it as a relational field of action filled with local patterns of value- and meaning-laden engagement among residents, and between them and "foreigners," artifacts, and the sociomaterial environments they inhabit and pass through. Culture, understood this way, manifests itself most clearly in pronouncements of valuation, signification, and taste. ${ }^{7}$ Taste, in turn, refers to both cultural discernment and the human senses, exemplifying how bodily engagement is historically tied to both consumption and production.

The directed use of the body is best understood as a historical phenomenon informed by the (changing) contexts of material and knowledge production and consumption in which humans operate. To investigate this, I introduced the term "sensuous technology," affording an understanding of the senses as both historically configured and configuring; this in keeping with their interaction with material culture and "social" and "literary technology." This approach fits well with studies that attend to the ways humans live in the world through their senses and how this varies historically and culturally. "Sensuous chemists" thus appear as

\footnotetext{
${ }^{6}$ Andre Gunder Frank, "Review of Kenneth Pomeranz, The Great Divergence," Lournal of Asian Studies, 2001, 60:180-182; Samuel P. Huntington, The Clash of Civilizations and the Remaking of World Order (New York: Simon \& Schuster, 1996); David Landes, The Wealth and Poverty of Nations: Why Some Are So Rich and Some So Poor (New York: Norton, 1998), pp. 516, 523; and Margaret Jacob, The First Knowledge Economy: Human Capital and the European Economy, 1750-1850 (Cambridge: Cambridge Univ. Press, 2014).

${ }^{7}$ Steven Lubar and W. David Kingery, History from Things: Essays on Material Culture (Washington, D.C.: Smithsonian Books, 1995).

${ }^{8}$ On the directed use of the body as a historical phenomenon see Lissa Roberts, "The Death of the Sensuous Chemist: The 'New' Chemistry and the Transformation of Sensuous Technology," Studies in Historv and Philosophv of Science, 1995, 26:503-529; revised as "The Death of the Sensuous Chemist: The Changing Role of Sense Evidence in the Establishment of Modern Chemistry," in Empire of the Senses: The Sensual Culture Reader, ed. David Howes (Oxford: Berg, 2005), pp. 106-127; and Roberts, "The Senses in Philosophy and Science: Blindness and Insight," in A Cultural History of the Senses in the Age of Enlightenment, ed. Anne Vila (London: Bloomsbury, 2014), pp. 109-132. See Steven Shapin, "Pump and Circumstance: Robert Boyle's Literary Technology," Social Studies of Science, 1984, 14:481-520; Alain Corbin, The Foul and the Fragrant (Cambridge, Mass.: Harvard Univ. Press, 1986); and Bruce Moeran, "Japanese Fragrance Descriptives and Gender Constructions: Preliminary Steps Toward an Anthropology of Olfaction,” Etnofoor, 2005, 18:97-123.
} 
especially important actors, involved in productive pursuits ranging from agriculture and mining to processing countless substances and manufacturing countless commodities. Far from trivial, this reveals much about the history of production.

Production's reliance on sensible engagement, even in the context of technological intervention, nuances the sharp distinctions often drawn between manual and artisanal labor, on one side, and supposedly rational, mechanized production on the other. Simultaneously, while use of the senses was productively ubiquitous, it was not uniform, due to a marriage of physical (climate, habitat, individual bodily characteristics, etc.) and cultural factors (customs, values, aesthetics, and consumption patterns). Finally, highlighting the role of human senses in the history of production provides a gateway for thinking about the environmental contexts in which bodies were productively engaged and the consequences they experienced in relation to consumable products and pollution.

\section{THE HISTORY OF PRODUCTION AS ENVIRONMENTAL HISTORY}

One might expect the current conjuncture between economic and environmental crises to stimulate research regarding the historical relation between production and "the environment." While interesting work has been done from various perspectives to configure and analyze this relationship, at least three issues inhibit this line of investigation beyond individual or regional studies. First, mainstream economics and economic history continue to treat production in quantitative or business-related terms and environmental issues as externalities. Second, for those who practice history as a matter of regional comparisons, integrating an environmental dimension is complicated by the fact that environmental conditions, processes, and impacts refuse to be neatly limited by national or regional borders. Third, much environmental history posits an essential distinction between "nature" and "culture," which stands in the way of recognizing "the environment" as a historically evolving, hybrid result of human and material interaction. ${ }^{9}$ This alternate view requires us to consider the history of production as "always already" environmental history - not only because of the environmental consequences of cycles of production, use, and consumption, but more fundamentally in terms of the environmental embeddedness of all human activity.

Adopting this perspective brings with it a need to treat human agency and the active presence of artifacts and materials more symmetrically. Numerous studies examining, theorizing, and debating the agency of artifacts exist. Slightly different are studies that help us understand the sociomaterial environment as involving a tension between human-material collaboration and the forces that remain outside the disciplining order of these networks. Chandra Mukerji's study of the Canal du Midi provides an inspiring model, particularly because it analyzes both "strategic" and "logistic" power, the latter of which entails organizing the material world in ways that affect the social order. Similarly, Andrew Pickering presents the history of engineering along the Mississippi River as a cautionary tale of what happens when engineers act as if "nature" were a distinct and essentially static realm to be subdued and

\footnotetext{
9 John Foster and Brett Clark, "The Paradox of Wealth: Capitalism and Ecological Destruction," Monthly Review, 2009, 11:1-11, https://monthlyreview.org/2009/11/01/the-paradox-of-wealth-capitalism-and-ecological-destruction/ (accessed 2 Sept. 2014); and Kenneth Pomeranz, "Introduction: World History and Environmental History," in The Environment and World History, ed. Edmund Burke III and Pomeranz (Berkeley: Univ. California Press, 2009), p. 3. On the distinction of nature and culture in environmental history see James Beattie et al., "Rethinking the British Empire Through Eco-cultural Networks," Environment and Historv, 2014, 20:561-575; Sara Pritchard, Confluence: The Nature of Technology and the Remaking of the Rhône (Cambridge, Mass.: Harvard Univ. Press, 2011); and Pritchard, Dolly Jørgensen, and Finn Arne Jørgensen, eds., New Natures: Joining Environmental History with Science and Technology Studies (Pittsburgh, Pa.: Univ. Pittsburgh Press, 2013).
} 
controlled. A number of historians have begun attending to the active presence of materials in the history of chemistry, with an eye toward revealing the complex human-material interplay involved in chemically-based production and its governance. ${ }^{10}$ Particularly given that current concerns with human impact on the environment have heightened to the point that many speak of the "Anthropocene," consideration of how humans simultaneously rely on and change the environments they inhabit through active collaboration with materials seems an approach worth developing.

\section{GOVERNANCE}

"Governance" is not a pretty word; too often it conjures images of bureaucratized processes aimed at managing society and "the economy" in line with a particular political vision. What really matters from this perspective are less the boring processes than the underlying ideologies, which help explain why so many studies of this period (1750-1850) focus on analyzing the contrasting concepts of "free market" liberalism and mercantilism. But considering production as practice invites us to analyze governance practices as interactive elements of historical evolution, rather than simply to grant causal agency to abstract concepts and the historical actors who articulated them. By combining this consideration with the recognition that governance is not only about what governments do, but that it refers also to the stimulation and management of production through organized social initiative, we can appreciate the impact of its omnipresence. This recognition includes attending to the formative roles of colonial administration, taxation regimes, and support for sectors such as the military. So too does it point to organizations such as oeconomic and improvement societies that helped stimulate and expand the circulation of knowledge and experience in the hopes of engineering communities populated by productive and morally upright citizens. In all these cases, we must attend to the interplay of governance with material and knowledge production, interactions that involved encouragement, management, and use in ways that simultaneously stimulated and shaped productivity. ${ }^{11}$

\section{FRAMING COMPARATIVE HISTORY}

Readers familiar with my work know that I join those who argue for setting the history of science and technology in a context of globally situated interconnections, exchanges, and

\footnotetext{
${ }^{10}$ On the agency of artifacts see Langdon Winner, "Do Artifacts Have Politics?" Daedalus, 1980, 109:121-136; David Noble, "Social Choice in Machine Design: The Case of Automatically Controlled Machine Tools," Politics and Societv, 1978, 8:313-347; and Barry Andrews, Material Politics: Disputes Along the Pipeline (Oxford: Wiley-Blackwell, 2013). See Chandra Mukerji, Impossible Engineering: Technology and Territoriality on the Canal du Midi (Princeton, N.J.: Princeton Univ. Press, 2009); and Andrew Pickering, "New Ontologies," in The Mangle in Practice: Science, Society, and Becoming, ed. Pickering and K. Guzik (Durham, N.C.: Duke Univ. Press, 2009), pp. 1-14. On the human-material interplay in chemical-based production see Van Driel, "Ashes to Ashes" (cit. n. 2); Van Driel and Roberts, "Circulating Salts" (cit. n. 2); and Roberts, Carin Berkowitz, Eugenia Lean, Projit Mukharji, and Emily Lynn Osborne, eds., Chemical Reactions: Chemistry and Global History (in preparation).

${ }^{11}$ John Brewer, The Sinews of Power (London: Routledge, 1989); and William Ashworth, "The Industrial Revolution and the Ideological Revolution: Science, Neoliberalism, and History," History of Science, 2014, 52:178-199. See also the essay by Karel Davids in this Focus section; Matthew Paskins, "The Society for the Encouragement of Arts, Manufactures, and Commerce and the Material Public Sphere," in Social Networks in the Long Eighteenth Century, ed. Ileana Baird (Cambridge: Cambridge Scholars, 2014), pp. 77-95; Lissa Roberts, ed., "Practicing Oeconomy during the Late Eighteenth Century," special issue, History and Technology, 2014, 30; Federico Marcon, "Satô Nobuhiro and the Political Economy of Natural History in Nineteenth-Century Japan," Japanese Studies, 2014, 34: 265-287; and William Ashworth, "Between the Trader and the Public: British Alcohol Standards and the Proof of Good Governance," Technology and Culture, 2001, 42:27-50.
} 
translations. This perspective complicates comparative history by demonstrating that local and regional identities are not built on a priori characteristics; they are evolving outcomes of much broader interconnections. As Thomas Misa has further demonstrated, it is crucial not to paper over local differences in a rush to offer generalizations about national or "civilizational" units. Moreover, the perspective from which historical comparisons are posed determines their reach and interpretive significance. ${ }^{12}$ What do we miss, then, when we privilege "economic growth" as the organizing principle of comparative history? Why should we be riveted toward an analysis of mechanized factory production as a kind of historical gold standard at the expense of other sorts and sectors of production? What happens when we privilege quantitative measures of output over qualitative issues that have much to tell us much about local and more geographically extensive developments, and might have set the stage for subsequent changes in production and consumption patterns? This is not to exclude the importance of comparative history, but to suggest the need to attend carefully to how it is framed.

This issue is especially relevant for the period of 1750 to 1850 , often characterized as having witnessed a "Great Divergence" between Western Europe and Asia, spurred by the former's industrialization and escape from traditional Malthusian growth limits. A growing body of literature examines this "Great Divergence," which can't be dealt with in detail here. ${ }^{13}$ Because achieving sustained economic growth is the fundamental point upon which these discussions base their comparisons, I limit myself to examining the consequences of organizing comparative history around economic measures. I then conclude with reference to the historical roots of current discussions of divergence.

\section{THE LIMITS OF ECONOMIC ANALYSIS}

Various scholars have argued convincingly that economics and its mode of analysis are culturally and historically bound. The "rationality" enshrined in most economic theory, for example, is the product of a particular, historically generated milieu. Further, not only do economists' contemporary concerns color their interpretations of the past. Economics also bears a performative impact on the present and future; it "performs, shapes and formats the economy, rather than observing how it functions." 14

\footnotetext{
${ }^{12}$ Simon Schaffer, Lissa Roberts, Kapil Raj, and James Delbourgo, eds., The Brokered World: Go-Betweens and Global Intelligence, 1780-1820 (Sagamore Beach, Mass.: Science History, 2009); Roberts, ed., "Accumulation and Management in Global Historical Perspective," special issue, History of Science, 2014, 52; Roberts, "Situating Science in Global History: Local Exchanges and Networks of Circulation," Itinerario, 2009, 33:9-30; Sujit Sivasundaram, "Science and the Global: On Methods, Questions, and Theory," Isis, 2010, 101:146-158; Micol Seigel, "Beyond Compare: Comparative Method after the Transnational Turn," Radical History Review, 2005, 91:62-90; Thomas Misa, From Leonardo to the Internet: Technology and Culture from the Renaissance to the Present (Baltimore: Johns Hopkins Univ. Press, 2004), pp. 59-96; and Bray, "Only Connect" (cit. n. 1).

${ }_{13}$ Peer Vries, Escaping Poverty: The Origins of Modern Economic Growth (Vienna: Vienna Univ. Press, 2013); Vries, State, Economy, and the Great Divergence: Great Britain and China, 1680s-1850s (London: Bloomsbury, 2015); and Julia Adenay Thomas, "Reclaiming Ground: Japan’s Great Convergence," Lapanese Studies, 2014, 34:253-263.

${ }^{14}$ Michel Callon, "Introduction," in The Laws of the Market in Economics, ed. Callon (Oxford: Blackwell, 1998), pp. 1-57, 2 (quotation); Lissa Roberts, "Practicing Oeconomy During the Second Half of the Long Eighteenth Century: An Introduction," Historv and Technology, 2014, 30:133-148; Pierre Bourdieu, "Making the Economic Habitus: Algerian Workers Revisited," Ethnography, 2000, 1:17-41; David Cannadine, "The Present and the Past in the English Industrial Revolution, 1880-1980," Past and Present, 1984, 103:131-172; and Philip Mirowski and Edward Nik-Khah, "Command Performance: Exploring What STS Thinks It Takes to Build a Market," in Living in a Material World: Economic Sociology Meets Science and Technology Studies, ed. Trevor Pinch and Richard Swedberg (Cambridge, Mass.: MIT Press, 2008), pp. 89-128.
} 
Does this mean that historians ought to abandon all reference to economic vocabulary and concepts? Gayatri Spivak suggests instead, "it is possible to put the economic text "under erasure,' to see, that is, the unavoidable and pervasive importance of its operation and yet to question it as a concept of the last resort." By appreciating how economic concepts, theories, and policies direct us toward and away from certain relational aspects of the world - thereby affecting our understanding, plans, and actions - we can reflect on what is at stake in a perspective that externalizes certain relations under categories such as "culture" and domesticates categories such as "the environment" through a process of formalization. Accepting such a stance has enormous political implications. But it also bears important analytical consequences for how we understand production in quite mundane ways. The economic understanding of humans as "rational actors," for example, allows calculation to stand in for the complexities of qualitatively heterogeneous human interaction. ${ }^{15}$ Considering production from a qualitative standpoint invites us instead to recognize the important roles played by colors, scents, patterns, textures, and flavors in relation to both production processes and consumer preferences, as well as to the locally specific values that lent meaning and significance to production itself. ${ }^{16}$

Because so many discussants of the "Great Divergence" focus on causes and indicators of contrasting economic growth, they tend to be interested in particular kinds of history of science and technology. Narratives of industrialization through the application of Newtonian mechanics, entrepreneurial know-how, and the innovative exploitation of energy sources (especially steam technology), recently repackaged as histories of "useful knowledge," thus retain pride of place. Alongside the stimulus of innovation, however, production often was (and remains) reliant on already available technology, knowledge, and productive processes, driven by local tastes, values, and valuation rather than always arising from some overriding urge toward efficiency and profit maximization (itself the expression of culturally specific values)..$^{17}$

Fixation on technological innovation flags a number of problems. Too often, innovation is treated as a story of applied knowledge, despite all that has been written about the linear model's inadequacy. Second, it is often presented as the (iconic) manifestation of an essentially Western "scientific culture" or "knowledge system" that was distinct from those found elsewhere. Third, that "culture" or "knowledge system" is itself often portrayed in a way that privileges mechanical physics above historically important work involving the investigation and use of materials, plants, and animals. Significantly, it is the still underappreciated history of chemistry that most informatively encompasses the interrelated examination and use of materials, plants, and animals, and that promises to be perhaps the most telling source for investigating production in Eurasia. ${ }^{18}$

\footnotetext{
${ }^{15}$ Gayatri Spivak, "Some Speculations on the Question of Value," Diacritics, 1985, 15:73-93, p. 85 (quotation); S. Charuscheela and Eiman Zein-Elabdin, eds., Postcolonialism Meets Economics (London: Routledge, 2003); and Esther-Mirjam Sent, "Behavioral Economics: How Psychology Made Its (Limited) Way Back into Economics," History of Political Economy, 2004, 36:735-760.

${ }^{16}$ Roberts, "Sensuous Chemist" (cit. n. 8); Roberts, "Blindness and Insight" (cit. n. 8); Lubar and Kingery, History from Things (cit. n. 7); and Ursula Klein and Emma Spary, eds., Materials and Expertise in Early Modern Europe: Between Market and Laboratory (Chicago: Univ. Chicago Press, 2010).

${ }^{17}$ Joel Mokyr, The Enlightened Economy (New Haven, Conn.: Yale Univ. Press, 2012); Jacob, First Knowledge Economy (cit. n. 6); David Edgerton, Shock of the Old: Technology and Global History (Oxford: Oxford Univ. Press, 2007); and David Arnold. Evervdav Technologv: Machines and the Making of India's Modernity (Chicago: Univ. Chicago Press, 2013).

${ }^{18}$ Marcos Barbosa de Oliveira, "Technology and Basic Science: The Linear Model of Innovation," Scientiae Studia, 2014, 12:129-146; Fa-ti Fan, British Naturalists in Qing China (Cambridge, Mass.: Harvard Univ. Press, 2004); Harold J. Cook,
} 


\section{THE GREAT DIVERGENCE'S HISTORICAL ROOTS}

One reason it remains difficult for some to break free from viewing distinctions between "the West and the Rest" as somehow based on something essential is that European sources from the period 1750-1850 are redolent with just this kind of rhetoric. But historical claims to a monopoly on "science" and "reason" were often invoked to establish and maintain sociocultural hierarchies both within and beyond Europe. ${ }^{19}$ By effacing the mindful-handedness and translations through which English shipwrights, Indian dyers, Chinese colorists, and others fed European elites' understanding and abilities with narratives that separated out and claimed "reason" and "science" as innately European, these elites justified their position and the disciplinary regimes that supported it. Appreciating such claims as a cultural trope thus tells us more about cultural attitudes and perspectives than it does about historical fact.

Recognizing the power wielded especially by steam-powered ships and automatic weaponry, non-European "reformers" during this time and since actually helped reify this trope by marrying "modernization" projects with an adoption of Western categories to rewrite their own future-directed histories on one hand, and with the adaptation of those categories to fit local needs, interests, and values on the other. But if we want to go beyond these interested interpretations, which simultaneously color the past and gesture toward a consequentially informed future, we need to adopt other criteria and categories of historical analysis. Rather than ground comparative histories in models of economic growth and "modernization" that tend to essentialize geographical and cultural divisions and externalize both environmental and cultural issues, this essay proposes an alternative. Beginning with salts, a family of substances involved in a broad range of production processes across the regions of Eurasia, it examines production in terms of its sociomaterially rooted, embodied practices. It thereby frees production from its usual cramped interpretation, wedged between business and economic calculations on one hand, and the culturally rich significance attributed to consumption patterns on the other. Production reveals itself instead as encompassing telling interactions between bodily engagement, cultural norms and values, materials, regimes of encouragement and regulation, and the environment.

\footnotetext{
Matters of Exchange (New Haven, Conn.: Yale Univ. Press, 2007); Londa Schiebinger and Claudia Swan, eds., Colonial Botany (Philadelphia: Univ. Pennsylvania Press, 2007); and Roberts, "Practicing Oeconomy" (cit. n. 11). On the history of chemistry as a means to investigate the history of production see Ursula Klein and Carsten Reinhardt, eds., Objects of Chemical Inquiry (Sagamore Beach, Mass.: Science History, 2014); Klein and Spary, Materials and Expertise (cit. n. 16); Klein, ed., "Artisanal-Scientific Experts in Eighteenth-Century France and Germany," special issue, Annals of Science, 2012, 69; Roberts, John Perkins and Simon Werrett, eds., Situating Chemistry, 1760-1840 (Leiden: Brill, forthcoming); and Roberts et al., Chemical Reactions (cit. n. 10).

${ }^{19}$ Giorgio Riello, "Asian Knowledge and the Development of Calico Printing in Europe," Journal of Global History, 2010, 5:1-28; Simon Schaffer, “"The Charter'd Thames': Naval Architecture and Experimental Spaces in Georgian Britain,” in The Mindful Hand: Inquiry and Invention from the Late Renaissance to Early Industrialization, ed. Lissa Roberts, Simon Schaffer, and Peter Dear (Amsterdam: Edita, 2007); and Roberts, "Blindness and Insight" (cit. n. 8).
} 